\title{
Identification of virulence factors in 16S-23S rRNA intergenic spacer genotyped Staphylococcus aureus isolated from water buffaloes and small ruminants
}

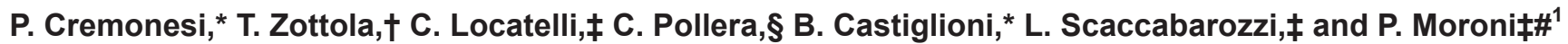 \\ *Istituto di Biologia e Biotecnologia Agraria, Consiglio Nazionale delle Ricerche, via Einstein, 26900, Lodi Italy \\ †lstituto Zooprofilattico Sperimentale delle Regioni Lazio e Toscana, Sezione di Latina, Strada Congiunte Destre loc. Chiesuola, 04100 Latina, \\ Italy \\ fUniversità degli Studi di Milano, Dipartimento di Scienze Veterinarie per la Salute, la Produzione Animale e la Sicurezza Alimentare, \\ 20133 Milan, Italy \\ §Università degli Studi di Milano, Dipartimento di Scienze Veterinarie e Sanità Pubblica, via Celoria 10, 20133 Milan, Italy \\ \#Cornell University, Animal Health Diagnostic Center, Quality Milk Production Services, 240 Farrier Road, Ithaca, NY 14853
}

\begin{abstract}
Staphylococcus aureus is an important human and animal pathogen, and is regarded as an important cause of intramammary infection (IMI) in ruminants. Staphylococcus aureus genetic variability and virulence factors have been well studied in veterinary medicine, especially in cows as support for control and management of IMI. The aim of the present study was to genotype 71 Staph. aureus isolates from the bulk tank and foremilk of water buffaloes $(\mathrm{n}=40)$ and from udder tissue (n $=7)$ and foremilk $(\mathrm{n}=24)$ from small ruminants. The method used was previously applied to bovine Staph. aureus and is based on the amplification of the 16S-23S rRNA intergenic spacer region. The technique applied was able to identify different Staph. aureus genotypes isolated from dairy species other than the bovine species, and cluster the genotypes according to species and herds. Virulence gene distribution was consistent with genotype differentiation. The isolates were also characterized through determination of the presence of 19 virulence-associated genes by specific PCR. Enterotoxins A, C, D, G, I, J, and L were associated with Staph. aureus isolates from buffaloes, whereas enterotoxins C and $\mathrm{L}$ were linked to small ruminants. Genes coding for methicillin resistance, Panton-Valentine leukocidin, exfoliative toxins $\mathrm{A}$ and $\mathrm{B}$, and enterotoxins $\mathrm{B}, \mathrm{E}$, and $\mathrm{H}$ were undetected. These findings indicate that RNA template-specific PCR is a valid technique for typing Staph. aureus from buffaloes and small ruminants and is a useful tool for understanding udder infection epidemiology.
\end{abstract}

Received April 11, 2013

Accepted September 9, 2013.

${ }^{1}$ Corresponding author: paolo.moroni@unimi.it
Key words: Staphylococcus aureus, water buffalo, small ruminant, virulence factor

\section{INTRODUCTION}

Staphylococcus aureus is a worldwide pathogen causing several severe diseases. In ruminants, it is the most common etiological agent of subclinical and clinical mastitis (Watts, 1988), with relevant losses in the dairy industry, as it reduces milk quality, milk production, and increases the cost of production through increased culling. Staphylococcus aureus strains produce several virulence factors such as (1) surface proteins that promote colonization of host tissues, (2) proteins that promote bacterial spread in tissues (e.g., leukocidin, kinases, and hyaluronidase), (3) biochemical properties that enhance their survival in phagocytes (e.g., carotenoids and catalase production), (4) surface factors that inhibit phagocytic engulfment (e.g., capsule, protein A), (5) immunological "target like" (e.g., protein A, coagulase, clumping factor, biofilm production), (6) membranedamaging toxins that lyse eukaryotic cell membranes (e.g., hemolysins, leukotoxin, and leukocidin), (7) exotoxins that damage host tissues or otherwise provoke symptoms of disease [e.g., staphylococcal enterotoxins SEA to SEQ, toxic shock syndrome toxin-1 (TSST-1), and exfoliative toxins (ET)], and (8) mechanisms of resistance to antimicrobial agents.

Some virulence factors are expressed by genes that are located on mobile genetic elements called pathogenicity islands (e.g., TSST and some enterotoxins; Novick, 2003) or lysogenic bacteriophages [e.g., Panton-Valentine leukocidin (PVL); Narita et al., 2001] and factors associated with suppressing innate immunity, such as the chemotaxis inhibitory protein and staphylokinase, which are integrated in the bacterial chromosome. All these factors can contribute in differ- 
ent ways to Staph. aureus pathogenicity and, therefore, influence the management of the disease (Dinges et al., 2000; Peacock et al., 2002). The molecular mechanisms responsible for the disease manifestation are not completely understood but differences in gene content and allelic variations between Staph. aureus strains are presumed to influence the pathogenesis of infections in cattle (Peacock et al., 2002). The importance of evaluating the combination of Staph. aureus virulence factors has been repeatedly emphasized both in human and veterinary medicine (Jarraud et al., 2002; von Eiff et al., 2004), and knowledge about the genetic variability within different Staph. aureus populations would help in the design of efficient therapeutic approaches. Actually, the genotype involved affects the prevalence of Staph. aureus and the number of infected quarters within a herd (Fournier et al., 2008). Although staphylococcal virulence factors have been identified in many Staph. aureus collections isolated from cases of bovine IMI, it is still unknown which factors are specifically associated with water buffalo and small ruminant IMI. The aim of the present study was to genotype and characterize Staph. aureus isolated from the milk of water buffaloes, small ruminants, and from udder tissue of sheep.

\section{MATERIALS AND METHODS}

\section{Farm Selection and Isolates Identification}

In the context of a pilot project focused on the improvement of welfare and control of SCC in water buffaloes and small ruminants in different areas of Latina County (Italy), 212 herds were sampled with the following distribution: 162 water buffaloes, 37 sheep, and 12 goats. Thirty-eight (18\%) of these were positive for Staph. aureus in bulk tanks and 18 farms decided to collaborate for further analyses. From those farms [5 sheep (A to E), 2 goats (F to G), and 11 buffaloes (H to T)], a total of 71 Staph. aureus isolates, originating from water buffaloes $(\mathrm{n}=40)$, sheep $(\mathrm{n}=22)$, and goats $(\mathrm{n}=9)$, were collected. All isolates were selected and stored at Istituto Zooprofilattico Sperimentale Lazio Toscana (IZSLT, Rome, Italy) Latina section, which is the main reference laboratory for the bacterial analyses on those species in the Lazio Region. All milk samples were collected and kept at $4^{\circ} \mathrm{C}$ until bacteriological analyses were performed according to the National Mastitis Council (NMC, 1999). A total of 7 sheep udder tissues from herd A were also examined. Parenchymal and cisternal tissues were collected from udder for bacteriological investigations and sections were sampled with a sterile swab that was rotated inside a 2-cm-long cut over a surface of $1 \mathrm{~cm}^{2}$ and then streaked on a sheep blood agar plate and Baird-Parker agar plates. After incubation of 24 to $48 \mathrm{~h}$ at $37^{\circ} \mathrm{C}$, suspect colonies were picked up from culture plates according to their cultural features (colony appearance and hemolysis) and subcultured on sheep blood agar. Then, their presumptive identification as Staph. aureus was confirmed by a tube coagulase test.

\section{DNA Extraction}

The coagulase-positive isolates were inoculated in brain-heart infusion broth (Oxoid Ltd., Basingstoke, UK) and incubated aerobically overnight at $37^{\circ} \mathrm{C}$. The DNA was extracted from $1 \mathrm{~mL}$ of culture broth (about $10^{8}-10^{9} \mathrm{cfu} / \mathrm{mL}$ ), following the instructions described in Cremonesi et al. (2006), starting from step 2. The quantity and quality of DNA samples were measured using a NanoDrop ND-1000 spectrophotometer (NanoDrop Technologies Inc., Wilmington, DE). The DNA samples were then stored at $-20^{\circ} \mathrm{C}$ until use.

\section{S-23S rRNA Intergenic Spacer Genotyping}

The method of Jensen et al. (1993), rearranged by Fournier and coworkers (2008), was used for RNA template-specific PCR (RS-PCR) genotyping. This method is based on the amplification of the 16S-23S rRNA intergenic spacer region. In a total volume of 25 $\mu \mathrm{L}$, each reaction contained $1 \times$ HotStarTaq Master Mix (Qiagen GmbH, Hilden, Germany), an 800 n $M$ concentration of each primer (G1:GAAGTCGTAACAAGG and L1:CAAGGCATCCACCGT), and $30 \mathrm{ng}$ of DNA. The amplification protocol was $95^{\circ} \mathrm{C}$ for $15 \mathrm{~min}$, which was followed by 27 cycles at $94^{\circ} \mathrm{C}$ for $1 \mathrm{~min}$, a 2 -min ramp to reach the final temperature, and annealing at $55^{\circ} \mathrm{C}$ for $7 \mathrm{~min}$. After a further 2-min ramp to reach the final temperature, extension was done at $72^{\circ} \mathrm{C}$ for $2 \mathrm{~min}$. The PCR products were then analyzed using an Agilent 2100 Bioanalyzer with a DNA 7500 LabChip kit (Agilent Technologies Inc., Palo Alto, CA). For interpretation of the results, 2 patterns were considered different if 2 or more peaks of the electropherogram differed in size. Groupings of the RS-PCR profiles were obtained with the BioNumerics 5.0 software package (Applied Maths NV, Sint-Martens-Latem, Belgium) using the unweighted pair group method cluster analysis.

\section{Molecular Strain Characterization}

All DNA samples were analyzed by PCR to determine the presence of genes encoding enterotoxins (from sea to $s e l$ ), leukotoxins (lukE, luk $\mathrm{S} / \mathrm{F}-\mathrm{PV}, l u k \mathrm{E}, l u k \mathrm{D}$, and $l u k \mathrm{M})$, acquisition of methicillin resistance $(m e c \mathrm{~A})$ and other virulence genes using primers and protocols described in the literature and listed in Table 1. The 
Table 1. Target genes, primer sequences, and PCR amplification products

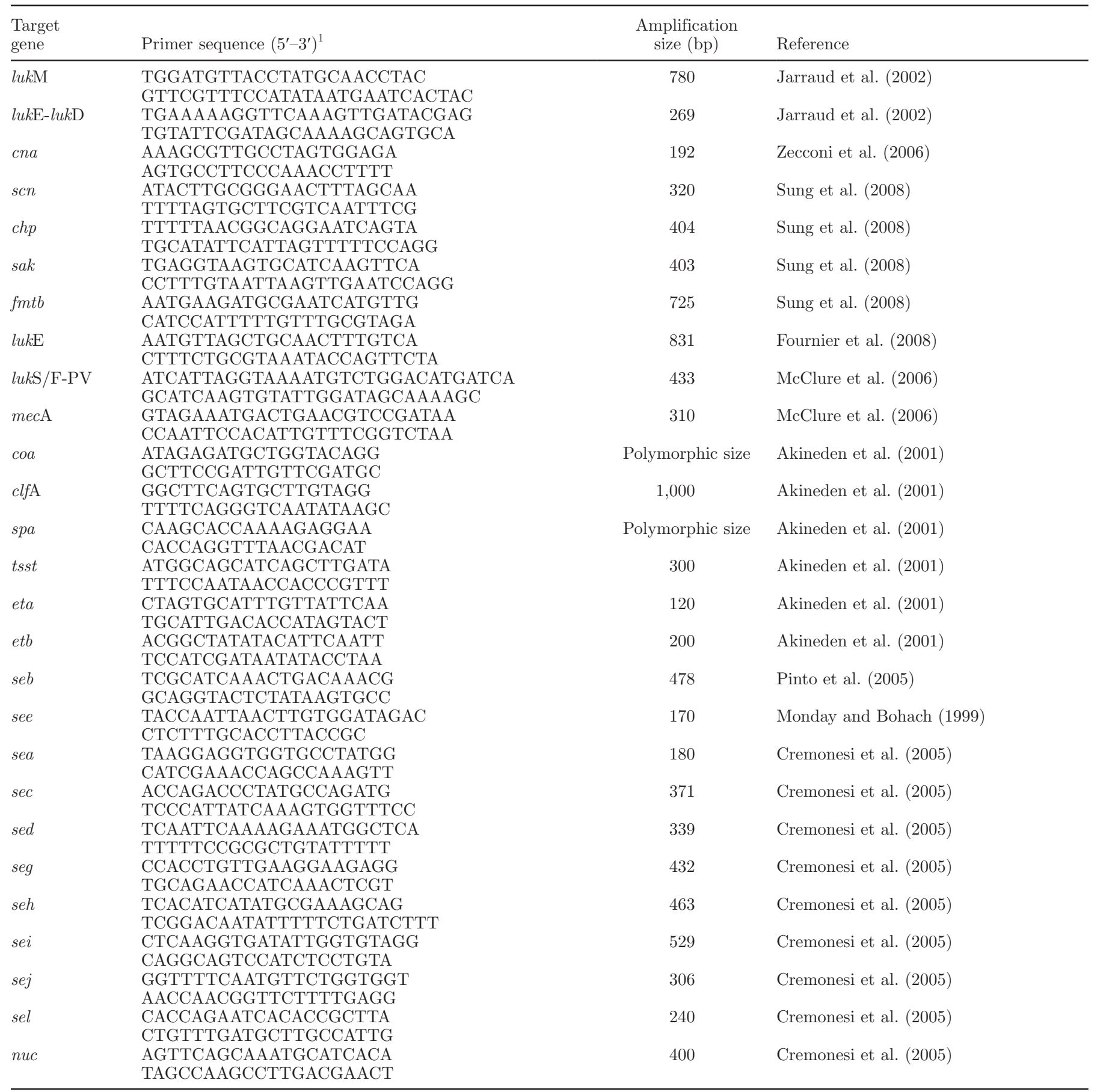

\footnotetext{
${ }^{1}$ For each target gene, the first primer is the forward primer and the second primer is the reverse primer.
}

amplified PCR fragments were distinguished by $2 \%$ agarose gel electrophoresis (GellyPhor; EuroClone SpA, Milan, Italy), stained with ethidium bromide $(0.05 \mathrm{mg} /$ $\mathrm{mL}$; Sigma-Aldrich, Milan, Italy), and visualized by UV transilluminator (BioView Ltd., Nes Ziona, Israel). A 100-bp DNA ladder (Finnzymes, Espoo, Finland) was included in each gel electrophoresis.

\section{RESULTS}

\section{RS-PCR Genotyping}

Water Buffalo. The genotyping analysis of the 40 isolates from milk samples, revealed the presence of 23 different profiles from 11 herds (Figure 1). One of these 
profiles (XXI) was common for 6 Staph. aureus isolated from bulk tank milk of the same herd (herd O), which was nonenterotoxigenic and with amplicons longer than 100 and $640 \mathrm{bp}$ for the x-region of protein $\mathrm{A}$ and coa genes, respectively. In the same herd, 4 other profiles (XX, XXII, XXIII, and XXIV) were detected among bulk tank isolates. Another profile (XXXII) was common to 4 isolates from foremilk in herd $\mathrm{S}$ and was the only one detected in that herd. The remaining profiles resulted from the analysis of 1,2 , or 3 isolates from samples collected in the same or in different herds, revealing the presence of up to 3 different strains in only 1 herd $(\mathrm{P})$.

Ovine. As described in Figure 1, analysis of the 16S23S rRNA intergenic spacer of 22 isolates from milk and udder halves in 5 different herds revealed 7 diverse profiles. Out of the 7 diverse profiles, 2 were the most frequent, as they made up $9(41 \%)$ and $6(27.2 \%)$ isolates, respectively; both were isolated from the same farm. In the first profile, the isolates were obtained both from milk and udder tissue and were positive for sec and sel genes, with the amplicon for the x-region of protein $\mathrm{A}$ gene longer than $100 \mathrm{bp}$ and the coa amplicon at 640 bp. Two of 9 isolates were negative for $l u k \mathrm{E}$ and 4 were negative for clfA genes. Within the second profile, 5 out of 6 isolates were enterotoxigenic (positive for sec and sel), with amplicons for the x-region of protein A gene and coa longer than 100 and $640 \mathrm{bp}$, respectively. The other 5 RS-PCR profiles resulted from the analysis of 1,2 , or 3 strains isolated from samples collected in different herds.

Caprine. Analysis of 16S-23S rRNA intergenic spacer for the 9 isolates collected from foremilk in 2 different herds revealed 4 different profiles, 3 of which belonged to the same cluster, with a similarity of $80 \%$ (Figure 1). In herd F, a single Staph. aureus isolate (CAP664) appeared more related to the ovine profiles. It was nonenterotoxigenic and negative for tsst, LukE$L u k \mathrm{D}, L u k \mathrm{M}-L u k \mathrm{~F} / \mathrm{PV}$, and $c l f \mathrm{~A}$ genes, showing a different profile from typical isolates from caprine samples (Table 2).

\section{Molecular Characterization}

All isolates were positive for coagulase (coa), thermonuclease (nuc) and membrane protein associated with antibiotic resistance $(f m t B)$ genes and negative for genes involved in host-cell invasion ( $e t a$ and $e t b$ ), in methicillin resistance $(m e c \mathrm{~A})$, for Panton-Valentine leukocidin $l u k \mathrm{~S} / \mathrm{F}-\mathrm{PV}$ and for SEB, SEE, and SEH enterotoxins.

Polymorphic Genes. The analysis of the coagulase gene (coa) and of the x-region of protein A gene (spa) produced amplicons of different size, which allowed for grouping the isolates in clusters based on the length of fragments obtained. Fourteen out of 40 (35\%) Staph. aureus water buffalo isolates gave a coa amplicon longer than $640 \mathrm{bp}$ and 26 out of 40 (65\%), an amplicon of $640 \mathrm{bp}$. The spa gene analysis yielded amplicons longer than 250 and $100 \mathrm{bp}$, respectively, for 17/40 (42.5\%) and 20/40 (50\%) isolates; 3 isolates analyzed did not produce an amplification product. For ovine isolates, amplification of the coa gene yielded amplicons longer than $640 \mathrm{bp}$ for $5 / 22(22.7 \%)$, lower than $640 \mathrm{bp}$ for $1 / 22(4.5 \%)$, and $640 \mathrm{bp}$ for $16 / 22(72.7 \%)$ isolates, whereas the analysis of spa genes produced amplicons longer than $100 \mathrm{bp}$ for $20 / 22(90.9 \%)$ and longer than 250 bp for $2 / 22(9.1 \%)$ isolates. For caprine isolates, the coa gene produced amplicons of $640 \mathrm{bp}$ for $7 / 9(77.7 \%)$ and longer than $640 \mathrm{bp}$ for $2 / 9(22.2 \%)$ of isolates; contemporary spa gene analysis revealed amplicons longer than 100 and longer than $250 \mathrm{bp}$, respectively, for $7 / 9$ $(77.7 \%)$ and $2 / 9(22.2 \%)$ isolates.

Enterotoxins. Seventeen out of 40 (42.5\%) water buffalo isolates were enterotoxigenic, harboring at least 1 of the genes coding for A, C, D, G, I, J, and L enterotoxins. The most frequent genes detected were sea $(11 / 17)$ and sed $(7 / 17)$. A single isolate (BUF275) harbored 4 enterotoxin genes (sea, sec, sei, and sel); 4 (BUF250, BUF251, BUF252, BUF253) and 3 (BUF269, BUF271, BUF273) other isolates harbored 3 (combination of sea, sed, and sej; or sed, seg, and sei; or sea, sej, and sei) and 2 genes (sea and sed), respectively.

Seventeen out of $22(77.2 \%)$ ovine isolates were enterotoxigenic and coded for enterotoxins $\mathrm{C}$ and L. The same result was obtained from Staph. aureus isolates of caprine origin; all the isolates, except for 1 nonenterotoxigenic unrelated isolate (CAP664), harbored sec and sel genes.

Other Virulence Genes. As reported in Table 2, the $l u k \mathrm{E}$ gene was detected in $90.9,100$, and $85 \%$ of ovine, caprine, and water buffalo isolates, respectively, whereas 77.2 (ovine), 88.8 (caprine), and $75 \%$ (water buffalo) of isolates were positive for the clumping factor gene (clfA). Eight out of $9(88.8 \%)$ caprine isolates possessed the tsst gene that encodes the toxic shock syndrome toxin, whereas amplicons for these genes were not produced from water buffalo strains. Among the ovine samples, 14 out of 22 strains (63.6\%) were positive for the tsst gene.

Twenty-one out of 22 isolates for ovines, all strains isolated from caprines, and 38 out of 40 isolates for water buffaloes harbored a gene coding for a new leukotoxin (LukE-LukD); contemporarily 17/22, 9/9, and 4/40 isolates respectively from ovines, caprines, and water buffaloes were positive for $L u k \mathrm{M}-L u k \mathrm{~F} / \mathrm{PV}$, which has been identified in Staph. aureus isolated from bovine milk (Jarraud et al. 2002). Among the isolates, 


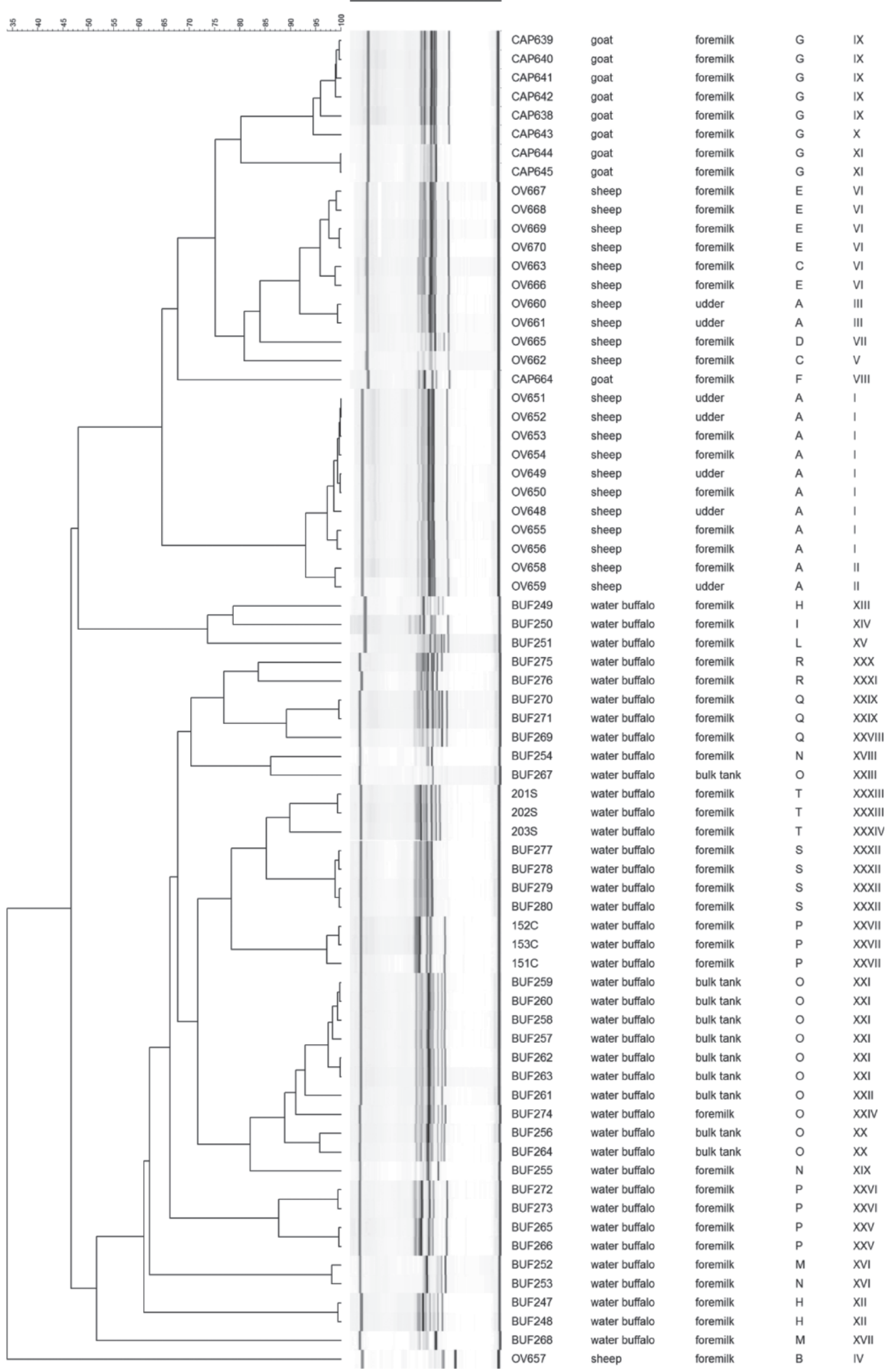

Figure 1. Dendrogram derived from the RNA template-specific PCR (RS-PCR) profiles generated during the analyses. The identities of the isolate, species (water buffalo, sheep, or goat), source (foremilk, udder, or bulk tank), herd (from A to T), and RS-PCR profile (from I to XXXIV) are reported for each sample. 
Table 2. Virulence genes and their relative frequency (\%) in water buffalo, ovine, and caprine isolates

\begin{tabular}{|c|c|c|c|}
\hline \multirow[b]{2}{*}{ Gene } & \multicolumn{3}{|c|}{ Positive isolates $[$ no. (\%)] } \\
\hline & $\begin{array}{l}\text { Water buffalo } \\
\quad(\mathrm{n}=40)\end{array}$ & $\begin{array}{c}\text { Ovine } \\
(\mathrm{n}=22)\end{array}$ & $\begin{array}{l}\text { Caprine } \\
(\mathrm{n}=9)\end{array}$ \\
\hline lukM & $4(10)$ & $17(77.2)$ & $9(100)$ \\
\hline$l u k \mathrm{E}-l u k \mathrm{D}$ & $38(95.0)$ & $21(95.4)$ & $9(100)$ \\
\hline cna & $31(77.5)$ & $10(45.4)$ & $1(11.1)$ \\
\hline$s c n$ & $19(47.5)$ & $8(36.6)$ & 1 (11.1) \\
\hline $\operatorname{chp}$ & $18(45.0)$ & $4(18.1)$ & 1 (11.1) \\
\hline$s a k$ & $30(75.0)$ & $9(40.9)$ & $3(33.3)$ \\
\hline$l u k \mathrm{E}$ & $34(85.0)$ & $20(90.9)$ & $9(100)$ \\
\hline clfA & $30(75.0)$ & $17(77.2)$ & $8(88.8)$ \\
\hline spa & $37(92.5)$ & $22(100)$ & $9(100)$ \\
\hline tsst & $0(0)$ & $14(63.6)$ & $8(88.8)$ \\
\hline sea & $11(27.5)$ & $0(0)$ & $0(0)$ \\
\hline $\mathrm{sec}$ & $1(2.5)$ & $17(77.2)$ & $8(88.8)$ \\
\hline sed & $7(17.5)$ & $0(0)$ & $0(0)$ \\
\hline seg & $6(15)$ & $0(0)$ & $0(0)$ \\
\hline sei & $6(15)$ & $0(0)$ & $0(0)$ \\
\hline sej & $2(5.0)$ & $0(0)$ & $0(0)$ \\
\hline sel & $1(2.5)$ & $17(77.2)$ & $8(88.8)$ \\
\hline
\end{tabular}

10 from ovines, 1 from caprines, and 31 from water buffaloes possessed the gene encoding the collagen-binding protein ( $c n a)$.

Some of the tested isolates harbored genes carried on mobile genetic elements and usually present in strains involved in human infections (Sung et al. 2008). The gene encoding the anti-opsonin staphylokinase ( $a k$ ) was present in $40.9,33.3$, and $75 \%$ of ovine, caprine, and buffalo isolates, respectively. In addition, the gene encoding the staphylococcal complement inhibitor (scn) was detected in 36.6, 11.1, and $47.5 \%$ of the isolates from ovines, caprines, and buffaloes. A positive reaction for the gene encoding the chemotaxis inhibitory protein $(c h p)$ was found in 18.1, 11.1, and $45 \%$ of the ovine, caprine, and buffalo isolates, respectively.

\section{DISCUSSION}

The epidemiology of Staph. aureus mastitis in dairy cattle has been studied using methods with high discriminatory powers during the past decade (e.g., pulsed-field gel electrophoresis, random amplified polymorphic DNA, spa-typing, and multilocus sequence typing; Haveri et al., 2007; Morandi et al., 2010). Despite the highly discriminative power, reproducibility, and portability that make them useful research tools, these methods are hardly applicable to daily practice. A simple technique based on the amplification of the 16S-23S rRNA intergenic spacer (RS-PCR) was used for genotyping in a short time numerous Staph. aureus isolates obtained from bovine herds in Switzerland (Fournier et al., 2008). In the current study, this technique was applied to the characterization of Staph. aureus isolated from bulk tank milk and foremilk of water buffaloes and from the udder and foremilk of small ruminants from herds located in different areas of the Lazio Region.

At $95 \%$ similarity, the genetic diversity among isolates recovered from water buffaloes and small ruminants showed that the 71 isolates were distributed over 34 different profiles and, except for 2 isolates (CAP664 and OV657), the analysis revealed a clustering in accordance with species (Figure 1) and, to some extent, with herds. Among these types, 6 isolates for water buffaloes, 5 for goats, and 9 for sheep belonged to a single RS-PCR genotype for each species isolated from the same farm. The isolates belonging to each of these 3 main profiles (Table 3) shared the same spa and coa amplicon lengths and were enterotoxigenic (isolates from both small ruminants species were positive for sec and $s e l$ ) and nonenterotoxigenic (isolates from water buffaloes). The other types were heterogeneous with regard to the presence of enterotoxin genes and $l u k \mathrm{E}$ and clfA genes as well as in length of coagulase gene and spa gene amplicons. This is in agreement with the findings that Staph. aureus from ruminant IMI constitutes a heterogeneous group but only a few specialized Staph. aureus types were responsible for most of the cases of IMI (Fournier et al., 2008; Aires-de-Sousa et al., 2007) and that these profiles have a broad geographic distribution (Annemüller et al., 1999; Smith et al., 2005).

Moreover, it has been demonstrated that a link exists between virulence gene patterns and specific genotypes and their epidemiological and pathogenic properties (Fournier et al., 2008). Actually, some genotypes are particularly contagious and prone to spread from cow 


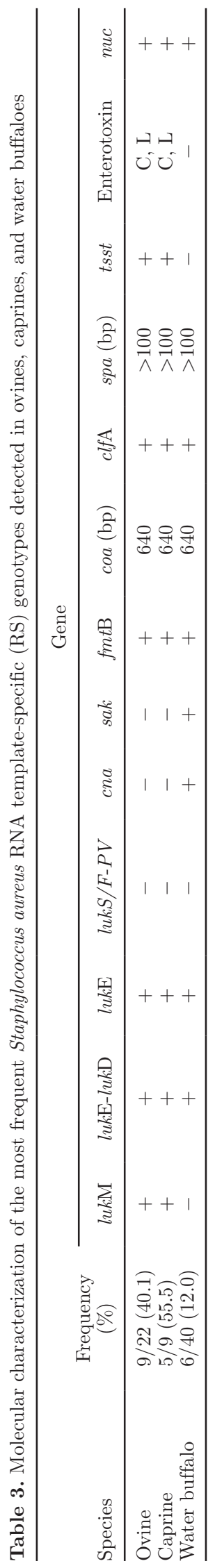

to cow and even between quarters within a cow. The results of the present work seem to confirm this statement in that some genotypes were identified in different animals within a herd (e.g., genotype I and VI in ovines, genotype IX in goats, and genotype XXXII in buffaloes). Despite remarkable heterogeneity, a single genotype is able to spread among animals on the same farm. The genotype has been found to be significantly associated to within-herd and within-cow prevalence of Staph. aureus and with quarter SCC (Fournier et al., 2008; Graber et al., 2009). We cannot confirm this aspect, as data about prevalence were not available for all isolates derived from farms characterized by udder problems due to Staph. aureus. The capability of Staph. aureus to adhere to extracellular matrix proteins is thought to be essential for colonization and the establishment of infections. Staphylococcus aureus-harboring genes coding for clumping factor ( $c l f A$ ), fibronectin-binding protein $(f m t B)$, and collagen-binding protein ( $c n a)$ are particularly fit to invade tissues. In particular, $f m t B$ and clf $A$ were widely present in isolates from all 3 species (Table 2) and in the 3 most widespread genotypes (Table 3). Genotype I from ovines and genotype IX from goats lacked $c n a$ and $s a k$, which were more widespread in isolates from buffaloes. Actually, both genes were present in at least $25 \%$ of buffalo Staph. aureus and in genotype XXI as well. Moreover, concerning toxins, a high correlation was confirmed between enterotoxins sec and sel in small ruminants, as previously described by Vimercati et al. (2006), whereas in water buffaloes, the linkages between sea, sed, and sej and between seg and sei were predominant, as in cows (Fournier et al., 2008). The fact that the enterotoxin genes seb, see, and seh were not detected was in concordance with the results of German (Zschöck et al., 2005) and Swiss studies (Stephan et al., 2002; Fournier et al., 2008) on bovine Staph. aureus.

In our study, all the isolates from water buffaloes were negative for TSST, whereas $77.4 \%$ of the strains collected from small ruminants were positive for the tsst gene and for sec and sel genes as well, and all were located on the same bovine staphylococcal pathogenicity island (SaPIbov). The genes encoding PVL and $m e c \mathrm{~A}$ were completely absent in the 71 isolates analyzed. This result is different from other observations about mastitis-related strains isolated in cows (Rainard et al., 2003; Zecconi et al., 2006). Though performed on a limited sample of isolates, the current survey records the absence of the mecA gene in Staph. aureus from dairy ruminants other than the bovine, and of a damaging leukocidin such as PVL. Leukocidins could play an overall important role in avoidance of immune response and thus pathogenesis, as reported by Rainard et al. (2003). 
According to previous findings by Ikawaty et al. (2010), the 11 isolates (9 from ovine and 2 from caprine herds) encoding at least 2 virulence factors out of staphylococcal complement inhibitor $(s c n)$, chemotaxis inhibitory protein of Staph. aureus (chp), and staphylokinase ( $s a k)$ may have a human origin, because these virulence factors show activity only against the human innate immune system. The recovery of humanassociated Staph. aureus in bovine mastitis is common (Barlow et al., 2013) and their presence among water buffaloes and small ruminants isolates should be determined in future studies.

Knowledge about the epidemiology of Staph. aureus genotypes in dairy species and herds might help to formulate strategies for reducing the infection spreading and for focused treatments. Characterization of virulence gene profiles of these different Staph. aureus could help to predict clinical outcomes and especially to identify harmful strains. A linkage between virulence genes patterns and genotypes has been confirmed by the present study. To make decisions regarding infection management based on diagnosis and genotyping, a less-expensive and time-consuming method is required (Barlow et al., 2013). The findings of this study provide a contribution to the comprehension of Staph. aureus IMI in buffaloes and small ruminants and information to differentiate control measures according to pathogen and host features.

\section{ACKNOWLEDGMENTS}

The authors thank Stefano Morandi (Institute of Sciences of Food Production, ISPA-CNR, Milan, Italy) for the analyses with BioNumerics 5.0 software and Jessica C. Scillieri Smith and Frank Welcome from Cornell University (Ithaca, NY) for English text revision.

\section{REFERENCES}

Aires-de-Sousa, M., C. E. Parente, O. Vieira-da-Motta, I. C. Bonna, D. A. Silva, and H. de Lencastre. 2007. Characterization of Staphylococcus aureus isolates from buffalo, bovine, ovine, and caprine milk samples collected in Rio de Janeiro State, Brazil. Appl. Environ. Microbiol. 73:3845-3849.

Akineden, Ö., C. Annemüller, A. A. Hassan, C. Lämmler, W. Wolter, and M. Zschöck. 2001. Toxin genes and other characteristics of Staphylococcus aureus isolates from milk of cows with mastitis. Clin. Diagn. Lab. Immunol. 8:959-964.

Annemüller, C., C. Lämmler, and M. Zschöck. 1999. Genotyping of Staphylococcus aureus isolated from bovine mastitis. Vet. Microbiol. 69:217-224.

Barlow, J. W., R. N. Zadoks, and Y. H. Schukken. 2013. Effect of lactation therapy on Staphylococcus aureus transmission dynamics in two commercial dairy herds. BMC Vet. Res. 9:28.

Cremonesi, P., B. Castiglioni, G. Malferrari, I. Biunno, C. Vimercati, P. Moroni, S. Morandi, and M. Luzzana. 2006. Technical note: Improved method for rapid DNA extraction of mastitis pathogens directly from milk. J. Dairy Sci. 89:163-169.
Cremonesi, P., M. Luzzana, M. Brasca, S. Morandi, R. Lodi, C. Vimercati, D. Agnellini, G. Caramenti, P. Moroni, and B. Castiglioni. 2005. Development of a multiplex PCR assay for the identification of Staphylococcus aureus enterotoxigenic strains isolated from milk and dairy products. Mol. Cell. Probes 19:299-305.

Dinges, M. M., P. M. Orwin, and P. M. Schlievert. 2000. Exotoxins of Staphylococcus aureus. Clin. Microbiol. Rev. 13:16-34.

Fournier, C., P. Kuhnert, J. Frey, R. Miserez, M. Kirchhofer, T. Kaufmann, A. Steiner, and H. U. Graber. 2008. Bovine Staphylococcus aureus: Association of virulence genes, genotypes and clinical outcome. Res. Vet. Sci. 85:439-448.

Graber, H. U., J. Naskova, E. Studer, T. Kaufmann, M. Kirchhofer, M. Brechbühl, W. Schaeren, A. Steiner, and C. Fournier. 2009. Mastitis-related subtypes of bovine. Staphylococcus aureus are characterized by different clinical properties. J. Dairy Sci. 92:1442-1451.

Haveri, M., A. Roslöf, L. Rantala, and S. Pyörälä. 2007. Virulence genes of bovine Staphylococcus aureus from persistent and nonpersistent intramammary infections with different clinical characteristics. J. Appl. Microbiol. 103:993-1000.

Ikawaty, R., E. C. Brouwer, E. van Duijkeren, D. Mevius, J. Verhoef, and A. C. Fluit. 2010. Virulence factors of genotyped bovine mastitis Staphylococcus aureus isolates in the Netherlands. Int. J. Dairy Sci. 5:60-70.

Jarraud, S., C. Mougel, J. Thioulouse, G. Lina, H. Meugnier, F. Forey, X. Nesme, J. Etienne, and F. Vandenesch. 2002. Relationships between Staphylococcus aureus genetic background, virulence factors, agr groups (alleles), and human disease. Infect. Immun. 70:631-641.

Jensen, M. A., J. A. Webster, and N. Straus. 1993. Rapid identification of bacteria on the basis of polymerase chain reaction-amplified ribosomal DNA spacer polymorphisms. Appl. Environ. Microbiol. 59:945-952.

McClure, J. A., J. M. Conly, V. Lau, S. Elsayed, T. Louie, W. Hutchins, and K. Zhang. 2006. Novel multiplex PCR assay for detection of the staphylococcal virulence marker Panton-Valentine leukocidin genes and simultaneous discrimination of methicillin-susceptible from -resistant staphylococci. J. Clin. Microbiol. 44:1141-1144.

Monday, S. R., and G. A. Bohach. 1999. Use of multiplex PCR to detect classical and newly described pyrogenic toxin genes in staphylococcal isolates. J. Clin. Microbiol. 37:3411-3414.

Morandi, S., M. Brasca, R. Lodi, L. Brusetti, C. Andrighetto, and A. Lombardi. 2010. Biochemical profiles, restriction fragment length polymorphism (RFLP), random amplified polymorphic DNA (RAPD) and multilocus variable number tandem repeat analysis (MLVA) for typing Staphylococcus aureus isolated from dairy products. Res. Vet. Sci. 88:427-435.

Narita, S., J. Kaneko, J. Chiba, Y. Piémont, S. Jarraud, J. Etienne, and Y. Kamio. 2001. Phage conversion of Panton-Valentine leukocidin in Staphylococcus aureus: Molecular analysis of a PVLconverting phage, phiSLT. Gene 268:195-206.

NMC (National Mastitis Council). 1999. Laboratory Handbook on Bovine Mastitis. Rev. ed. NMC, Madison, WI.

Novick, R. P. 2003. Mobile genetic elements and bacterial toxinoses: The superantigen-encoding pathogenicity islands of Staphylococcus aureus. Plasmid 49:93-105.

Peacock, S. J., G. D. de Silva, A. Justice, A. Cowland, C. E. Moore, C. G. Winearls, and N. P. Day. 2002. Comparison of multilocus sequence typing and pulsed-field gel electrophoresis as tools for typing Staphylococcus aureus isolates in a microepidemiological setting. J. Clin. Microbiol. 40:3764-3770.

Pinto, B., E. Chenoll, and R. Aznar. 2005. Identification and typing of food-borne Staphylococcus aureus by PCR-based techniques. Syst. Appl. Microbiol. 28:340-352.

Rainard, P., J.-C. Corrales, M. B. Barrio, T. Cochard, and B. Poutrel. 2003. Leucotoxic activities of Staphylococcus aureus strains isolated from cows, ewes, and goats with mastitis: Importance of LukM/ LukF'-PV leukotoxin. Clin. Diagn. Lab. Immunol. 10:272-277.

Smith, E. M., L. E. Green, G. F. Medley, H. E. Bird, L. K. Fox, Y. H. Schukken, J. V. Kruze, A. J. Bradley, R. N. Zadoks, and C. G. Dowson. 2005. Multilocus sequence typing of intercontinental bo- 
vine Staphylococcus aureus isolates. J. Clin. Microbiol. 43:47374743.

Stephan, R., K. Buehler, and C. Lutz. 2002. Prevalence of genes encoding enterotoxins, exfoliative toxins and toxic shock syndrome toxin 1 in Staphylococcus aureus strains isolated from bulk-tank milk samples in Switzerland. Milchwissenschaft 57:502-504.

Sung, J. M., D. H. Lloyd, and J. A. Lindsay. 2008. Staphylococcus aureus host specificity: Comparative genomics of human versus animal isolates by multi-strain microarray. Microbiology 154:1949-1959.

Vimercati, C., P. Cremonesi, B. Castiglioni, G. Pisoni, P. J. Boettcher, A. Stella, G. Vicenzoni, and P. Moroni. 2006. Molecular typing of Staphylococcus aureus isolated from cows, goats and sheep with intramammary infections on the basis of gene polymorphisms and toxins genes. J. Vet. Med. B Infect. Dis. Vet. Public Health $53: 423-428$. von Eiff, C., A. W. Friedrich, G. Peters, and K. Becker. 2004. Prevalence of genes encoding for members of the staphylococcal leukotoxin family among clinical isolates of Staphylococcus aureus. Diagn. Microbiol. Infect. Dis. 49:157-162.

Watts, J. L. 1988. Etiological agents of bovine mastitis. Vet. Microbiol. 16:41-66.

Zecconi, A., L. Cesaris, E. Liandris, V. Daprà, and R. Piccinini. 2006. Role of several Staphylococcus aureus virulence factors on the inflammatory response in bovine mammary gland. Microb. Pathog. 40:177-183.

Zschöck, M., B. Kloppert, W. Wolter, H. P. Hamann, and C. H. Lämmler. 2005. Pattern of enterotoxin genes seg, seh, sei and sej positive Staphylococcus aureus isolated from bovine mastitis. Vet. Microbiol. 108:243-249. 